\title{
A COGNITIVE ANALYSIS OF THE CROSS-LINGUISTIC DIFFERENCES BETWEEN ENGLISH AND SPANISH MOTION VERBS AND ITS IMPLICATIONS FOR THE FOREIGN TRANSLATION
}

Cristina Pascual Aransáez

Universidad de La Rioja

\section{ABstract}

In this paper I attempt to analyse the cross-linguistic differences between English and Spanish motion verbs from a cognitive perspective in order to shed some light on the difficulties they pose to the Spanish translator. In order to do so, I shall follow Langacker's cognitive grammar $(1987,1990)$ and in particular Talmy's event-frame analysis $(1985,1988,1991)$. However, I differ from these authors in my belief that the new Contrastive Analysis as expounded in James (1980) may prove fruitful as a methodological tool. Therefore, I will apply $\mathrm{CA}$ in the cognitive analysis of verbs of movement in English and Spanish.

The present paper constitutes a cognitive analysis of the cross-linguistic differences between motion verbs in English and Spanish and the difficulties they pose to Spanish translators. Cross-linguistic differences in the use of motion verbs have been traditionally treated as unrelated phenomena in stylistic 
manuals for translators (Vinay and Darbelnet, 1975, Malblanc, 1977). Nevertheless, the universalist-cognitive analysis of motion events carried out by some linguists (Langacker, 1987, 1990, Talmy, 1985, 1988, 1991) can prove useful in order to provide a comprehensive and unified account of them.

Little research has been carried out in this field '. In "Typology and rhetoric: Verbs of motion in English and Spanish» (forthcoming) Slobin adopts a cognitive perspective in order to shed some light on the strategies the translator has to use in order to translate an English-language novel. In this paper, I shall follow Talmy's proposals in order to attempt an analysis of the problems that English motion verbs pose to Spanish translators, but my approach will differ from Slobin's because in contrast to him I shall use contrastive analysis (henceforth CA) as a tool into my analysis. Such an analysis may be very useful in order to provide a detailed explanation of the specific differences in the syntactic construction and the expressive potential of motion verbs, which is lacking in Slobin's work.

I shall proceed in three stages. First, I shall begin with an overview of the theoretical constructs of cognitive theories which I will use in my analysis. Second, I shall carry out a cognitive study of the motion verbs that appear in Oscar Wilde's "The Happy Prince» and its Spanish translation, applying CA as expounded in James (1995). The samples I will use have been taken out from a corpus of 97 English motion verbs and the corresponding ones in Spanish. Third, I shall attempt to determine the consequences that cross-linguistic differences in motion verbs have for the narrative style which seems to be typical of Spanish.

\section{MOTION VERBS FROM A COGNITIVE PERSPECTIVE}

Verbs are found in virtually all the languages of the world, and their existence is a characteristic feature of European languages in general. With respect to verbs, English is an «isolating» language (i.e. it has no inflexional features), whereas Spanish is an «inflexional» language ${ }^{2}$ (i.e. its verbal features are expressed almost entirely by inflexion). Nevertheless, the type of information they carry does not vary greatly: English and Spanish verbs indicate time and

I Some linguists (Lindner, 1983, Morgan, 1997) have carried out cognitive analyses of English verbs of movement, but they have focused on a different aspect, namely the relevance of metaphor theory as a means to establish sematic systematicity.

2 See Palmer (1968) and Molho (1975) on general descriptions of the verb in English and Spanish respectively. 
there is a relation between tense and time. Verbs in English and Spanish have finite and non-finite form, and they may be classified in terms of full verbs and auxiliaries. In both languages there is an active and passive voice which differ from each other rather than in specific semantic features in the syntactic relations with other elements of the clause.

Motion verbs are used very frequently in both English and Spanish. However, each language differs from the other in its specific ways of constructing them syntactically and expressing their potential. We shall study the differences between English and Spanish motion verbs from a cognitive perspective, and thus first we shall discuss the lines of research followed by two cognitive linguists, namely Ronald W. Langacker and Leonhard Talmy.

Both Langacker's and Talmy's proposals show that motion verbs differ in the portions of an event they highlight. In Langacker's Cognitive Grammar $(1987,1990)$ sentences are analysed in terms of prominence. Following the general cognitive principle of figure/ground segregation, he states that in a simple transitive clause the verb expresses the relationship between the syntactic figure or «trajector» (i.e. the subject) and the syntactic ground or «landmark» (i.e. the object). Taking the conceptual analysis of motion events one step further, Talmy uses the notion of «event-frame», which is constituted by «a set of conceptual elements and relationships that (...) are evoked together or co-evoke each other" (Ungerer and Schmid, 1997). One of the types of event-frames Talmy has identified is motion event-frames. The structure of a motion event is formed by six components: the four central components MOTION, FIGURE («trajector»), GROUND («landmark») and PATH (along which the object moves), and the two optional ones, MANNER (of the movement) and CAUSE (of the movement).

Talmy contends $(1985,1991)$ that the cognitive components of motion event-frames are universal, but he adds that they are not expressed in the same way in all languages. According to the way in which they express PATH ${ }^{3}$, he divides languages into two categories, namelyverb-framed languages and satelite-framed languages. The former render PATH through the verb, whereas the latter express it by a particle, which he labels into the grammatical category of «satellite» ${ }^{4}$. Verb-framed languages include the Romance languages (Spanish

PATH can be considered to be one of the most important elements of the motion event, because it connects the other central components (MOTION, FIGURE, GROUND). In Ungerer \& Schmid's own words (1997: 237), it performs a framing function.

4 Cross-linguistic differences in the expression of motion verbs in English and Spanish have been already dealt with in stylistic manuals for translators and learners (see Mott, 1996: 156ff, 276ff). Nevertheless, Talmy's cognitive approach sheds more light on this matter because he provides a unifying account of the different aspects of movement instead of describing them as if they were unrelated to each other. 
among them), Semitic languages, Japanese and others. Examples of satelliteframed languages are all the Indo-European languages (English among them) except Romance, Finno-Ugric languages and Chinese.

It must be stressed that the analysis of the differences between English and Spanish motion verbs is particularly meaningful, because these languages belong to separated categories. This fact poses serious problems to Spanish translators ${ }^{5}$, who have to face the difficult task of translating English verbs of movement into Spanish.

\section{A COGNITIVE ANALYSIS OF MOTION VERBS IN ENGLISH AND SPANISH}

Perhaps the first step translators have to take in order to overcome the difficulties posed by English motion verbs is to compare and contrast them with the corresponding Spanish constructions. This have led me to apply a contrastive analysis to my cognitive study of verbs of movement in English and Spanish following James' orientation (1980). Although the theoretical validity and practical value of the traditional CA was strongly criticized during the 1970s, there was an emergence of a new CA in the 1980 s and nowadays it is being reconsidered ${ }^{6}$ (Danesi, 1995, Anderman, 1996). As far as my study is concerned, the new CA has proved very fruitful because it has allowed me to carry out a detailed analysis of the similarities and differences in the expression of motion verbs ${ }^{7}$ in English and Spanish and the implications they have for the Spanish translator.

\section{Methodology}

I have analyzed a corpus of 97 English motion verbs and the corresponding ones in Spanish. The samples have been taken from a tale written by Oscar Wilde, namely «The Happy Prince», and its translation into Spanish produced by Julio Gómez de la Serna (El Crimen de Lord Arthur Savile y Otros

s As Gunilla Anderman has rightly pointed out (1996), apart from Spanish translators, native Spanish speakers also have to cope with these difficulties when learning English as a second language. See Gunilla Anderman (1996) for some relevant insights into this problem.

- Hoey \& Houghton (1997) have made some remarks on the relevance of CA as an aid to translation. See Baker (1992) for a more detailed analysis.

7 Under the term motion verb we understand not only the verbs of movement proper, such as go - ir, walk - andar, travel - viajar, but all kinds of verbs involving movement in space, whether self-induced or other induced relocation of objects, e.g., push - empujar, carry - llevar, etc. 
Relatos, 1994: pp. 53-65). I use 97 motion verbs as a corpus because this is the total amount of motion verbs present in «The Happy Prince». Despite the brevity of this tale, the number of motion verbs is large and this is the reason why I took it as the object of my analysis. The examples which are going to be analysed in the following pages have been chosen at random. I have decided that this should be so because I wish to claim the generality of my results to the whole work.

The following examples illustrate that English is a satellite-framed language, while Spanish is a verb-framed language:

(1) E. His friends had gone away to Egypt six weeks before.

Sp. Seis semanas antes habian marchado sus compañeras a Egipto.

(2) E. ... tears were running down his golden cheeks.

Sp. ... lágrimas que se deslizaban por sus mejillas de oro.

(3) E. ... the yellow lions come down to the water's edge to drink.

Sp. ... los rubios leones bajan a beber a la ribera del río.

(4) E. You must go away to Egipt.

Sp. Debes marchar a Egipto.

As we can observe, the general tendency in English is to render PATH by a particle, while Spanish expresses it through the verb. This is not only the case with motion verbs proper. Any English verb which involves movement in space needs a particle in order to indicate PATH. The next examples of verbs which express relocation of objects provide linguistic evidence for it:

(5) E. So the Swallow picked out the great ruby from the Prince's sword.

Sp. Y entonces la golondrina arrancó el soberbio rubí de la espada del Príncipe.

(6) E. I cannot pluck out your eye.

Sp. No puedo arrancaros ese ojo.

(7) E. He picked up crumbs ...

Sp. Picoteaba las migas ...

(8) E. We must throw it away.

Sp. Habrá que tirarlo. 
This shows that the English verb needs a particle (out, up, away) in order to express the direction followed by an object when it is moved. Although English has some verbs which include PATH (leave, rise, fall $^{8}$ ), they constitute a small minority of the motion verbs:

(9) E. Then another drop fell.

Sp. Y entonces le cayó una nueva gota.

(10) E. When the moon rose...

Sp. En cuanto salió la luna...

Some English motion verbs have a French origin (enter, exit, cross, arrive, traverse, ascend, descend ), and they incorporate the PATH in the verb meaning:

(11) E. ... at night-time he arrived at the City.

Sp. ... al anochecer llegó a la ciudad.

Since French is a verb-framed language, it is not surprising that these «French» verbs display this characteristic. They are similar to Spanish verbs of movement in their syntactic construction and expressive potential, and thus they are easily translated into Spanish. However, the Spanish translator who translates a Spanish text into English must bear in mind that these verbs do not belong to the core vocabulary; they are used in a formal style and are not very frequent.

The examples I have analysed so far confirm my previous claim that English motion verbs need a particle in order to express the path element in contrast to their Spanish counterparts, in which it is included. Talmy contends (1985) that the way the MANNER element is conveyed coincides with this difference. Nevertheless, it must be noted that when expressing MANNER, it is Spanish that uses a separate adverbial, while English incorporates it in the motion verb.

Let me illustrate this statement by providing some examples of verbs of movement proper in English and the corresponding Spanish constructions:

(12) E. ... he flew back to the Happy Prince.

Sp. ... volvió volando hacia el Príncipe Feliz.

* Although fall includes the PATH element implicitly, most of the times it is used with a particle in order to describe it. In "The Happy Prince" fall appears 6 times, and it carries a particle ( $i n$, on, down, out ) in four of them. 
(13) E. So the Swallow flew away to the student's garret.

Sp. Y entonces la golondrina fue volando hasta la guardilla del escritor.

(14) E. ... she ran home, laughing.

Sp. ... se marchó corriendo muy alegre a su casa.

In the sentences above there is evidence of the general tendency in Spanish when it is necessary to translate an English motion verb. In order to express MANNER, the Spanish translator uses a participle adverbially in such a way that the meaning of the participle is the one included in the main verb in the English version. Spanish translators also use nouns or prepositional phrases:

(15) E. ... they all flew away.

Sp. ... todas las golondrinas alzaron ${ }^{9}$ el vuelo.

(16) E. ... he flew away.

Sp. ... la golondrina emprendió el vuelo.

In Mott's words, «the Romance languages show a predilection for abstract nouns, but English prefers verbs because they have the advantage of being more vivid and concrete" (Mott, 1996: 163). Let us have a look at the following examples of verbs which express relocation of objects:

(17) E. ... you must take it off, leaf by leaf, ...

Sp. ... vete quitándolo hoja por hoja ...

(18) E. Leaf after leaf of the fine gold the Swallow picked off... $\mathrm{Sp}$. Hoja a hoja fue la golondrina desprendiendo el oro fino...

These examples above show how consistent the difference in the expression of MANNER between English and Spanish is. The cross-linguistic differences between English and Spanish motion verbs are clearly illustrated in Figure 1 .

* Notice that alzar hints at the manner of the movement -it is upwards. However, the noun which follows is necessary to specify it clearly. 


\begin{tabular}{ccccc}
\hline FIGURE & $\begin{array}{c}\text { MOTION } \\
\text { MANNER }\end{array}$ & PATH & GROUND \\
\hline $\begin{array}{c}\text { 1. a. } \\
\text { 1. b. }\end{array}$ & $\begin{array}{c}\text { The Swallow } \\
\text { The Swallow }\end{array}$ & $\begin{array}{c}\text { flew } \\
\text { flew }\end{array}$ & $\begin{array}{c}\text { across } \\
\text { into }\end{array}$ & $\begin{array}{c}\text { the harbour. } \\
\text { the room. }\end{array}$ \\
\hline & FIGURE & $\begin{array}{c}\text { MOTION } \\
\text { PATH }\end{array}$ & GROUND & MANNER \\
\hline $\begin{array}{l}\text { 2. a. } \\
\text { 2. b. }\end{array}$ & La golondrina & $\begin{array}{c}\text { atravesón } \\
\text { entró }\end{array}$ & $\begin{array}{c}\text { el puerto } \\
\text { a la habitación }\end{array}$ & $\begin{array}{c}\text { volando. } \\
\text { volando. }\end{array}$ \\
\hline
\end{tabular}

Figure 1. Event-frame analysis for an English sentence and its Spanish translation (after Ungerer and Schmid, 1997: 234)

THE TRANSLATION OF ENGLISH MOTION VERBS AND ITS IMPLICATION FOR SPANISH NARRATIVE STYLE

The translation of English motion verbs usually pose some difficulties for the Spanish translator. The reasons for it become self-evident, if we take into account the lexico-syntactic differences between English verbs of movement and the corresponding Spanish constructions. Baker points out that:

in translation, grammar often has the effect of a straitjacket, forcing the translator along a certain course which may or may not follow that of the source text as closely as the translator would like to. (Baker, 1992: 85)

The translation of motion verbs can serve as an illustration: Spanish needs to add to verbs a participle, a noun or a prepositional phrase in order to express manner, whereas this element is included in the English verb. This may prove troublesome for the translator, who realizes that formal equivalence $^{10}$ is not possible and dynamic equivalence cannot be easily achieved. Let us apply some strategies proposed by Baker (1992) to the cognitive analysis

11) I am following Nida, who distinguishes two types of equivalence, formal and dynamic. Formal equivalence means that the SL and TL words have similar orthographic or phonological features. Dynamic equivalence is based on the principle of equivalent effect (i.e. the SL and TL words having the same effect on their respective readers). For more details about equivalence, see Kenny, 1997. 
of the problems encountered by the translator when translating English motion verbs into Spanish.

Cross-linguistic differences between English and Spanish motion verbs result in some change in the "manner» information specified by the English verb. One strategy practised by Spanish translators is to omit this component when the verb of movement in English has no direct counterpart in Spanish:

(19) E. In he hopped,...

Sp. La golondrina penetró en la habitación, ...

(20) E. So he darted down, ...

Sp. Y entonces la golondrina alzó el vuelo, ...

Verbs like hop and dart are very difficult to translate into Spanish, and the translator has decided to use the Spanish terms penetrar and alzar el vuelo. In contrast to the English verbs, they do not indicate the manner in which the actions take place. Obviously, the effect that the translation produces to the Spanish readers is not exactly the same as the one the source text has upon its English readers. In other words, the loss of information provokes a slight loss of effect. However, we must bear in mind that the translator's task is not easy. An elaborate paraphrase can express the complete meanings of hop or dart, but the translator has probably decided to neglect the manner information in order to avoid stylistic awkwardness (one of the features of the so-called «translationese», see Anderman, 1996).

The translator may also decide to encode the relevant information lexically, as in the following examples:

(21) E. The Reed shook her head.

Sp. Éste se negó, moviendo la cabeza.

(22) E. Through this he darted, and came into the room.

Sp. La golondrina penetró por él como una flecha en el cuarto.

Example (21) shows another strategy practiced by Spanish translators, namely expressing manner by adding a participle to the verb of movement. In contrast to (19) and (20), the manner information in (21) is too relevant to be omitted. Therefore the translator has decided (rightly, in my opinion) that manner should be expressed explicitly. Example (22) is a good instance of how a translator can produce a longer sentence than the original and avoid stylistically awkwardness. Notice that the translator has used one verb instead of two, 
and has expressed manner through a well-known comparison (a very suitable one, because an arrow is very similar to a dart). In this way the translation keeps the swiftness and vividness which characterizes the source text, and it has not betrayed its original meaning. Translation is a creative process, not a mechanical activity and the translator can carry out some changes if he believes that they will improve his final product without altering the source text's meaning. It does not matter if the sentence in the source text is shorter than the resulting one in the target language. In fact, it is generally believed that a good translation tends to be longer than the original.

As it can be inferred from the examples I have been analysing, the Spanish translator's task is not easy when he deals with English motion verbs. First, he has to determine if manner information is relevant enough to be expressed or not. Second, he has to find a way of rendering manner which will not be too long or awkward. According to Anderman (1996: 50) the translator will learn how to do it with time and experience. However, I believe that some theoretical approaches can contribute to relieve him from some difficulties.

\section{CONCLUSION}

Analyses of cross-linguistic differences between English and Spanish motion verbs have traditionally been carried out from the point of view of translation studies. Therefore, they have been treated as stylistic differences which the translator had to take into account in order to improve his translation.

In the foregoing paper I have attempted to study cross-linguistic differences between motion verbs in English and Spanish from a cognitive perspective, using the overall framework of Cognitive Linguistics. This analysis has had two aims: first, I have attempted to show that these differences are the result of different ways of mapping cognitive elements onto linguistic ones. Second, I have studied the main difficulties Spanish translators encounter when dealing with motion verbs in order to try to shed some light on this matter.

Apart from the various constructs of cognitivism, I have also applied Contrastive Analysis as a methodological tool into my study. I think that it has been a useful means to explain - not to predict, as traditional CA intended- differences among English and Spanish.

It is the author's belief that translation studies may benefit from research on other areas. As I have pointed out above, a cognitive approach to translation studies is complementary to the studies carried out from other perspectives, and should lead to complementary conclusions, so that the final objective of a comprehensive all-embracing description of translation can be achieved. 


\section{REFERENCES}

Anderman, Gunilla (1996): «The Word is My Oister-The Language Learner and the Translator», Anderman, Gunilla \& Michael Rogers (eds.), Words, Words. The Translator and the Language Learner, Clevendon, Multilingual Matters. BAKER, M. (1992): A Coursebook on Translation, London, Routledge.

DANESI, MARCEL (1995): «Contrastive Analysis and Second Language Teaching Today: The Legacy of Robert J. Di Pietro», Fernández, J. \& Wallhead, C. (eds.), Temas de Linguística Aplicada, Granada, Universidad de Granada.

HoEY, Michael \& DiANE Houghton (1997): «Contrastive analysis and translation», Routledge, Baker, M. (ed.), Encyclopedia of Translation Studies, London, Routledge.

JAMES, CARL (1980): Contrastive Analysis, London, Longman.

KENNY, D., (1997), «Equivalence». Baker, M. (ed.), Routledge Encyclopedia of Translation Studies, London, Routledge.

LANGACKER, RONALD W. (1987): Foundations of Cognitive Grammar, vol.I: Theoretical Prerequesites, Stanford/California, Stanford University Press.

LANGaCKer, Ronald W. (1990): Concept, Image, and Symbol: the Cognitive Basis of Grammar, Berlin, New York, Mouton de Gruyter.

LiNDNER, SUSAN J. (1983): A Lexico-Semantic Analysis of English Verb Particle Constructions with out and $\mathrm{up}, \mathrm{PhD}$. diss. Reprinted Bloomington, Indiana University Linguistics Club.

Molho, Miguel (1975): Sistemática del Verbo Español (Aspectos, Modo, Tiempo), Alonso, Biblioteca Románica Hispánica, vol.I, Estudios y Ensayos, 229, Madrid, Gredos.

Morgan, Pamela S., (1997): «Figuring out figure out: Metaphor and the Semantics of the English Verb-Particle Construction», Cognitive Linguistics, vol. 8-4, 327. 357, Berlin, New York, Mouton de Gruyter.

MOTT, BRIAN (1996): A Spanish-English, English-Spanish Translation Companion for Spanish Learners of English, Barcelona, EUB.

PALMER, Fred R. (1968): A Linguistic Study of the English Verb, Miami Linguistic Series No. 2, Florida, University of Miami Press.

SLOBIN, DAN I. (forthcoming): «Typology and Rhetoric: Verbs of Motion in English and Spanish», Masayoshi Shibatani and Sandra A. Thompson eds, (forthcoming), Grammatical Constructions: Their Form and Meaning, Oxford, Oxford University Press.

TALMY, LeONHARD (1985): «Lexicalization Patterns: Semantic Structure in Lexical Forms», Shopen (ed.), Language Typology and Syntactic Description, vol.3: Grammatical Categories and the Lexicon, Cambridge, Cambridge University Press.

TALMY, LeONHARD (1988): «Force Dynamics in Language and Cognition», Cognitive Science, 12, 49-100, Berlin, New York, Mouton de Gruyter. 
TALMY, LeONHARD (1991): "Path to Realization: A Typology of Event Conflation», Proceedings of the Seventeenth Annual Meeting of the Berkeley Linguistics Society, Berkeley, Berkeley Linguistic Society, 480-519.

UNGERER, FRIEDRICH \& HANS-Jörg SCHMID (1997): An Introduction to Cognitive Linguistics, London, Longman.

Vinay, J-P. \& J. Darbelnet (1975): Stylistique Comparée du Français et de l'Anglais, nouvelle édition, Paris, Didier.

WILDE, OsCAR (1994):The Complete Works of Oscar Wilde, Collins Classics, Glasglow, Collins.

WILDE, OsCAR (1994): El Crimen de Lord Arthur Savile y Otros Relatos, Relato Corto Aguilar, Madrid, Aguilar. 